\title{
Comparative Study of Biological Agents, Trichoderma harzianum (Th- Azad) and Trichoderma viride (01PP) for Controlling Wilt Disease in Pigeon Pea
}

\author{
Mohammad Shahid ${ }^{1 *}$, Mukesh Srivastava ${ }^{1}$, Anuradha Singh ${ }^{1}$, Vipul Kumar $^{1}$, Smita Rastogi ${ }^{2}$, Neelam Pathak ${ }^{2}$ and AK Srivastava ${ }^{2}$
}

${ }^{1}$ Biocontrol Laboratory, Department of Plant Pathology, C.S. Azad University of Agriculture and Technology, Kanpur, UP, India

${ }^{2}$ Department of Biosciences, Integral University, Lucknow, UP, India

\begin{abstract}
The paper aims to study the morphological, physiological, molecular characterization and bio-formulation of Trichoderma harzianum (Th Azad) and Trichoderma viride 01PP-8315, an effective fungicide and a biological control agent too that protects the plants and seeds from other pathogenic fungi. The physiologic study is done in an attempt to find the effective management of the disease caused by soil borne pathogens. Trichoderma harzianum (Th Azad) and Trichoderma viride 01PP-8315 isolated from the infected soil samples of Pigeon pea fields and grown at preferable temperatures, $\mathrm{pH}$ and different solid and liquid culture media. Most preferable temperature for the growth and sporulation of Trichoderma harzianum (Th Azad) and Trichoderma viride 01PP-8315 has been observed up to $30^{\circ} \mathrm{C}(210.5 \mathrm{mg}$ dry weight of mycelium). A detailed morphology of the strain is done in this study including colony growth rate, colony color, colony edge, mycelial form, conidiation, conidiophore branching, conidial wall, conidial color, etc. The molecular characterization of the strain is carried out using an 18S rRNA gene sequence with the help of a universal Internal Transcribed Spacer marker that gives an amplicon of a total of 1173 base pairs and $546 \mathrm{bp}$ of the 18S rRNA gene was sequenced and used for the identification of isolated fungal strains that is later sequenced and allotted with Gene Bank Accession no. JX119211 and KC800922 respectively. To check the presence of endochitinase gene in two of the potential strains of Trichoderma species viz. T. harzianum (Th Azad) and $T$. viride 01PP an ech42 primer was used.
\end{abstract}

A talc based bio-formulation has been prepared with this strain where the population of the spores was found to decline after 180 days.

Keywords: Biocontrol; Trichoderma; Internal transcribed spacer; Sequencing; Polymerase chain reaction

\section{Introduction}

The paper summarizes a comparative study of Trichoderma harzianum (Th Azad) and Trichoderma viride 01PP to test their biocontrol efficacy against Fusarium causing wilt in a leguminous crop such as Pigeon pea grown in various farm fields of Uttar Pradesh, India. Trichoderma is well known for its inherent ability to antagonize the plant pathogenic fungi and stimulate plant growth and defense responses thereby acting as a potential biological control agent [1]. Mycoparasitism is the mode of action displayed by Trichoderma against other soil borne pathogenic fungi where it interacts directly with them and various studies have been done to describe the mechanism of action and the enzymes that aid in killing the pathogens. Trichoderma species attaches to the host hyphae via coiling, post host recognition, and then penetrates the cell wall by secreting certain cell wall degrading enzymes such as chitinases, glucanases, proteases, xylanases, etc. [2].

Pigeon pea is the most widely produced pulse crop in India sharing $40 \%$ of the total pulse production. Many high yielding varieties have been released till date but due to certain factors, disease as one among them hampers the total exploration of the potential variety. More emphasis is needed on disease management of this crop as this field lacks attention in spite of the importance it renders to the masses. Many chemicals are available for the control of different soil borne diseases of Pigeon pea and have maintained a strong paradigm but from the past few years, used of bio-agents in disease control has gained a significant momentum due to its certain beneficial effects and ecofriendly nature as compared to the chemicals that cause environmental degradation including pollution of surface and ground water and also soil besides increasing pest resurgence. Researches in biocontrol against soil borne plant pathogens were initiated during 1930s [3]. Trichoderma species have been gaining importance as a potential and effective biocontrol agent and also as a plant health promoter due to its fascinating mechanisms like the production of antifungal metabolites [4], competition for space and nutrients, mycoparasitism, induction of defense responses [5] and promotion of salinity and drought tolerance.

\section{Materials and Methods}

\section{Isolation and identification of Trichoderma viride 01PP-8315} and Trichoderma harzianum (Th Azad)/6796

The soil samples for the identification of Trichoderma viride 01PP8315 and for Trichoderma harzianum (Th Azad) /6796were collected from the experimental fields located at Hardoi district and Meja town of Allahabad district of Indiarespectively. Isolate of Trichoderma

*Corresponding author: Mohammad Shahid, Biocontrol Laboratory, Department of Plant Pathology, Chandra Shekhar Azad University of Agriculture and Technology, Kanpur, Uttar Pradesh, India, Tel: 0512-253-4156; E-mail: shahid.biotech@rediffmail.com

Received February 08, 2014; Accepted February 24, 2014; Published February 28, 2014

Citation: Shahid M, Srivastava M, Singh A, Kumar V, Rastogi S, et al. (2014) Comparative Study of Biological Agents, Trichoderma harzianum (Th-Azad) and Trichoderma viride (01PP) for Controlling Wilt Disease in Pigeon Pea. J Microb Biochem Technol 6: 110-115. doi:10.4172/1948-5948.1000130

Copyright: ( 2014 Shahid M, et al. This is an open-access article distributed under the terms of the Creative Commons Attribution License, which permits unrestricted use, distribution, and reproduction in any medium, provided the original author and source are credited 
Citation: Shahid M, Srivastava M, Singh A, Kumar V, Rastogi S, et al. (2014) Comparative Study of Biological Agents, Trichoderma harzianum (ThAzad) and Trichoderma viride (01PP) for Controlling Wilt Disease in Pigeon Pea. J Microb Biochem Technol 6: 110-115. doi:10.4172/19485948.1000130

species was isolated and identified in potato dextrose agar (PDA) with low sugar medium [6]. The identification of Trichoderma isolates were confirmed both by morphological and by molecular method.

\section{Evaluation of bio-agents against the pathogen}

For this study, the pathogen was isolated from the diseased plant of pigeon pea field from different places of UP area. One week old culture of Fusarium udum maintained on PDA petri plates at $28 \pm 10^{\circ} \mathrm{C}$ was used for the study of the effects of biocontrol agents isolated from the rhizosphere of wilt sick plot. Antagonistic activity of these biocontrol agents against test pathogen was determined by "dual culture" technique. Five $\mathrm{mm}$ disc of pathogen was taken from the actively growing colonies of the test pathogen and antagonists with the help of inoculating tools. The disc of the pathogen was placed on one side of in agar plates aseptically, and the antagonists were placed opposite side of the pathogen in same petri plates. Each treatment was replicated three times and incubated at $28 \pm 10^{\circ} \mathrm{C}$. Growth of antagonists and pathogen were recorded after $10 \mathrm{~d}$ of incubation. When the inhibition zone was formed, it was expressed as \% inhibition and was calculated by the following formula:

$$
\begin{aligned}
& \text { Inhibition } \%=\frac{C-T}{C} \times 100 \\
& \text { Where, } \\
& \mathrm{C}=\text { Growth of the colony in control (mm) } \\
& \mathrm{T}=\text { Growth of the colony in treated plates. }
\end{aligned}
$$

\section{Molecular identification of Trichoderma viride 01PP-8315 and Trichoderma harzianum (Th Azad)/6796 based on ITS markers}

Pure culture of the target fungus was grown overnight in liquid Potato Dextrose Broth medium for the isolation of genomic DNA using a method described by Hiney et al. [7]. The total genomic DNA was extracted from isolate of Trichoderma viride 01PP-8135 based on Cetrimide Tetradecyl Trimethyl Ammonium Bromide (CTAB) mini extraction method of Crowhurst et al. [8] with minor modification.

Internal Transcribed Spacer regions of the rDNA gene were used in combination and individually for molecular identification. Two universal primers, ITS-1 (5'-TCCGTAGGTGAACCTGCGG-3') as forward primer and ITS-4 (5'-TCCTCCGCTTATTGATATGC-3') as reverse primer, were used for the molecular identification that gives a uniform banding pattern for Trichoderma viride $01 \mathrm{PP}-8315$ strain. The PCR conditions are described below which resulted in an amplicon of $\sim 1173$ bp as seen in the gel.

PCR setup (denaturation, annealing and extension) details:

$\begin{array}{ll}\text { Step } 1 \text { (pre-denaturation) } & 940^{\circ} \mathrm{C}(5 \mathrm{~min}) \\ \text { Step } 2 \text { (denaturation) } & 940^{\circ} \mathrm{C}(30 \mathrm{sec}) \\ \text { Step } 3 \text { (annealing) } & 550^{\circ} \mathrm{C}(30 \mathrm{sec}) \\ \text { Step } 4 \text { (extension) } & 720^{\circ} \mathrm{C}(1.30 \mathrm{sec}) \\ \text { Step } 5 \text { (storage) } & 720^{\circ} \mathrm{C}(10 \mathrm{~min})\end{array}$

The genomic DNA was extracted from isolated fungal strain Trichoderma harzianum Th azad-6796 and universal ITS-1 forward primer and ITS-4 reverse primer were used for the amplification and sequencing of the $18 \mathrm{~S}$ rRNA gene fragment. The $18 \mathrm{~S}$ rRNA gene of 546 base pairs thus sequenced was used for the identification of isolated fungal strain from the soil sample. The PCR conditions are described below.

PCR setup (denaturation, annealing and extension) details:

Step 1 (pre-denaturation)

$940^{\circ} \mathrm{C}(5 \mathrm{~min})$

Step 2 (denaturation)

$940^{\circ} \mathrm{C}(1 \mathrm{~min})$

Step 3 (annealing)

$550^{\circ} \mathrm{C}(2 \mathrm{~min})$

Step 4 (extension)

$720^{\circ} \mathrm{C}(3 \mathrm{~min})$

Step 5 (storage)

$720^{\circ} \mathrm{C}(10 \mathrm{~min})$

\section{Sequence analysis}

Sequence analysis of the sequenced gene was initiated with the use of a similarity searching algorithm such as BLAST (Basic Local Alignment Search Tool). The gene of interest, $18 \mathrm{~S}$ rRNA of the test strains, was searched for similar gene sequences using nucleotide BLAST program against a non-redundant nucleotide (nr/nt) database [9]. The database sequences that were found to be $\sim 90 \%$ similar to the test sequence were selected as the best matching homologs and were then subjected to a Multiple Sequence Alignment in the Clustal W program [10].

Based on the multiple sequence alignment of the selected sequence set, an evolutionary distance matrix and a phylogenetic tree were then computed using the Neighbor-Joining method. MEGA (Molecular Evolutionary Genetics Analysis) version 4.0 was used for phylogenetic and molecular evolutionary analyses $[11,12]$.

The18S rRNA gene sequence of the test strain was again compared with a different set of sequence databases such as small subunit ribosomal RNA (SSU rRNA) and large subunit ribosomal RNA (LSU rRNA) using Ribosomal RNA BLAST program [13,14]. 18S rRNA gene sequence of test strain is also compared against those sequences in Ribosomal Database Project [15] by using the RDP Classifier check program. The annotated information for the sequence in the database to which $18 \mathrm{~S}$ rRNA aligns is used for the fungal identification.

\section{Identification of genes involved in fungal cell wall degradation}

The nucleotide sequences of all the isolated strains submitted to NCBI are retrieved and the genes responsible for cell wall degradation is identified and retrieved such as ech42, coding for endochitinase, The gene sequences are then analyzed using bioinformatics tools and methods. The following steps have been undertaken for the geneidentification:

1. Similarity search using BLAST: All the nucleotide sequences of the 2 isolated strains of Trichoderma sp. are searched in BLASTn tool for finding similar templates. The two strains showed significant similarity to the other strains of Trichoderma.

2. Sequence Analysis: The nucleotide sequences of the identified genes are searched for promoters using NNPP program. Promoter prediction is an important step in sequence analysis as it helps us to identify the coding regions and their location in the complete genomic sequence. The positions and patterns of the predicted promoters for the identified gene have been determined.

3. Gene-finding: Searching the query sequences against EST database and finding ORFs is the principle on which gene finding is based in this report. Variants of BLAST such as BLASTx, BLASTp and BLASTn (against EST database) are used 
Citation: Shahid M, Srivastava M, Singh A, Kumar V, Rastogi S, et al. (2014) Comparative Study of Biological Agents, Trichoderma harzianum (ThAzad) and Trichoderma viride (01PP) for Controlling Wilt Disease in Pigeon Pea. J Microb Biochem Technol 6: 110-115. doi:10.4172/19485948.1000130

for finding the coding regions and conserved domains present in the gene sequences. Genscan is used for peptide prediction and the peptides thus predicted are searched through BLASTx program for validation.

\section{Bio-formulation and its validation}

Talc powder was evaluated as a carrier material to produce bioformulation of Trichoderma species. The carrier was dried under sun, powdered (sieve pore: $1 \mathrm{~mm}$ ) and sterilized at $1.05 \mathrm{~kg} / \mathrm{cm}^{2}$ pressure for 30 minutes. The substrate was mixed with a 7 days old culture of Trichoderma viride 01PP-8315 and Trichoderma harzianum previously grown on PDA in 2:1 (solid culture) w/v and $5 \mathrm{~g} / \mathrm{kg}$ CMC was added as an adjuvant. Observations on colony forming units of Trichoderma species was recorded initially and at monthly intervals for up to 6 months for shelf life study.

\section{Results and Discussion}

The identified Trichoderma viride $01 \mathrm{PP}$ and Trichoderma harzianum (Th Azad) isolates were confirmed both by morphological Figure 1, and molecular characters (ITS) and deposited in Indian Type Culture Collection (ITCC), IARI, Pusa, New Delhi, NCBI Gene Bank Database and finally deposited to NBAIM, Mau, respectively (Accession No. received and listed in Table 1) .

The morphological descriptors used in the characterization of Trichoderma viride 01PP and Trichoderma harzianum (Th Azad) have been described in Table 2 they hold significance in rapid visual identification of the strain under study. The morphological characters of the fungus under study agree very closely with the description given by Vasudeva and Srinivasan [16] and Booth [17].

Antagonistic effect of the two strains against Fusarium oxysporum udum to check which strain is better.Bio-agents were evaluated for their inhibiting effective against the pathogen in vitro by "dual culture techniques" as described in material and method. The results of average diameter of fungal colony incubated at $28 \pm 1.0$ temperature after 10 days are presented in histogram (Figure 2). The results presented in histogram (Figures 3 and 4 ) revealed that all the bio-agents suppressed colony growth of Fusarium oxysporumf.sp. udum. The above findings are in close agreement with the findings of Singh and Mukhopadhyay [18] who reported that the antagonistic fungi like Trichoderma harzianum, Trichoderma viride, and Gliocladium virens inhibited the growth of pathogen by competition, mycoparasitism and antibiosis.

The $\mathrm{r}$ RNA based analysis is a central method in pathology used not only to explore microbial diversity but also to identify new strains. The

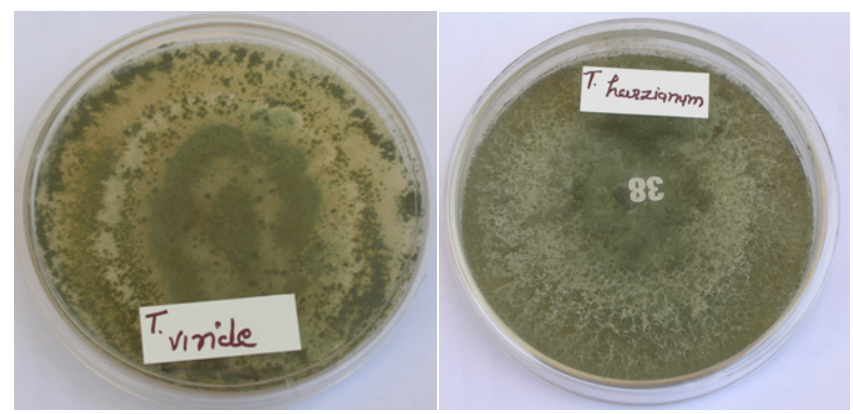

Figure 1: Colony Growth of Trichoderma viride (01 PP) and Trichoderma harzianum (Thazad) on PDA Medium.

\begin{tabular}{|l|l|l|l|l|l|l|}
\hline $\begin{array}{l}\text { Strain } \\
\text { No. }\end{array}$ & $\begin{array}{l}\text { Name of } \\
\text { Bio-agent }\end{array}$ & $\begin{array}{l}\text { Strain } \\
\text { code }\end{array}$ & Source & $\begin{array}{l}\text { ITCC Acc. } \\
\text { No }\end{array}$ & $\begin{array}{l}\text { Gen bank } \\
\text { NCBI No. }\end{array}$ & $\begin{array}{l}\text { NBAIM Acc. } \\
\text { No }\end{array}$ \\
\hline & T. viride & 01PP & Hardoi & 8315 & JX119211 & F-03110 \\
\hline $\begin{array}{l}\text { T. } \\
\text { harzianum }\end{array}$ & Thazad & $\begin{array}{l}\text { CSA Farm, } \\
\text { Kanpur }\end{array}$ & 6796 & KC800922 & F-03109 \\
\hline
\end{tabular}

Table 1: Identification of potential strains of Trichoderma sp.
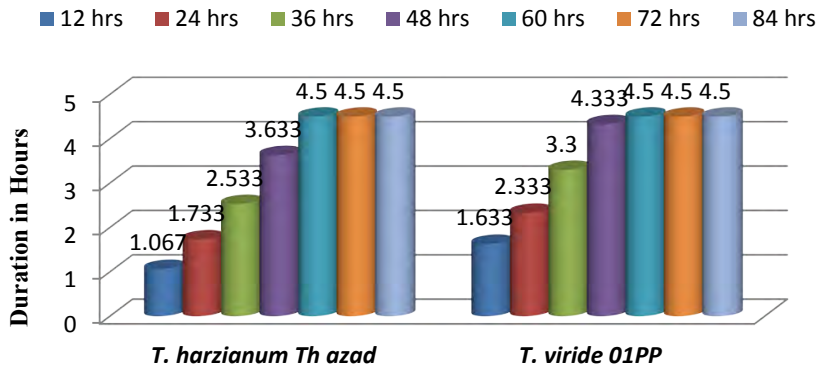

Figure 2: Growth kinetics of the two strains to justify which strain among the two grows faster.

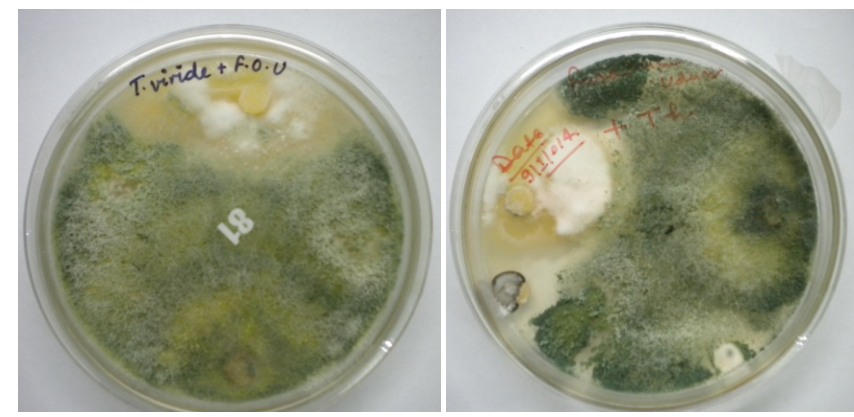

Figure 3: Antagonistic effect of Trichoderma viride (01PP), Trichoderma harzianum (Thazad) against Fusarium oxysporumudum in PDA Medium.

genomic DNA was extracted from isolated fungal strain Trichoderma viride 01PP-8315 and Trichoderma harzianum (Th Azad) and universal ITS- 1 primers $19 \mathrm{~F}$ and ITS-4 primers $20 \mathrm{R}$ were used for the amplification and sequencing of the $18 \mathrm{~S}$ rRNA gene fragment. A total of 1173 base pairs and $546 \mathrm{bp}$ of the 18S rRNA gene was sequenced and used for the identification of isolated fungal strains. Subsequently an 18S rRNA gene sequence based phylogenetic tree showing the relationships between the test strain 01PP and (Th Azad) and selected representatives of the genus Trichoderma is given in Figure 5. It is evident from phylogenetic analysis of $18 \mathrm{~S}$ rRNA gene that the isolate $01 \mathrm{PP}$ and (Th Azad) represents a genomic species in the genus Trichoderma. Comparison of test strain against known sequences of SSU rRNA and LSU rRNA databases showed that the gene sequence of isolate 01PP and (Th Azad) has 95\% sequence similarity (Score $=1608$ bits, Expect=0.0) with $18 \mathrm{~S}$ rRNA gene sequence of Trichoderma. Thus, data shows that the isolate 01PP and (Th Azad) is a member of the genus Trichoderma. The $18 \mathrm{~S}$ rRNA gene sequence of isolate $01 \mathrm{PP}$ and (Th Azad) were deposited in GenBank that was later allotted with an accession numbers i.e., JX119211\& KC800922. The results are in accordance with Mukherjee et al. [19], Lubeck et al. [20] also used universal primed (UP)-PCR and RFLPs of rDNA-ITS amplification for characterization of Trichoderma isolates from rice fields in the Philippines and from building materials respectively.

The primers for the identified gene were designed using in silico 
Citation: Shahid M, Srivastava M, Singh A, Kumar V, Rastogi S, et al. (2014) Comparative Study of Biological Agents, Trichoderma harzianum (ThAzad) and Trichoderma viride (01PP) for Controlling Wilt Disease in Pigeon Pea. J Microb Biochem Technol 6: 110-115. doi:10.4172/19485948.1000130

approach and these primers were used for identifying the Trichoderma strains in wet lab. In their defensive action, Trichoderma spp. apply cell wall degrading enzyme (Endochitinase) so defense mechanisms comprise both enzymatic and chemical weapons, which make Trichoderma spp. efficient mycoparasities, antagonists and biocontrol agents characteristics that can be exploited by using Trichoderma spp. or the metabolites secreted by these fungi as biological fungicides to fight plant diseases caused by pathogenic fungi. Thereby Trichoderma spp. plays an important role in defense mechanism and their exploitation [21,22].

The ech42 primer was used to detect the endochitinase gene in two of the potential strains of Trichoderma species viz. T. harzianum (Th Azad) and T. viride 01PP. From the Figure 6 given above, it is quite clear that the endochitinase gene is present in both species thus this can be used for the gene identification purpose. The above findings are in close agreement with the findings of Radheshyam and Sumangala [23].

The shelf life of Trichoderma viride 01PP-8315 and Trichoderma harzianum (Th Azad) in talc as a carrier material, determined at an interval of 30 days, indicated that the decline in the number of propagules started from 30th day onwards. Talc based bio-formulation was found to be the best material as it can retain the maximum number of viable propagules (which was $29.7 \times 10^{6} \mathrm{cfu} / \mathrm{g}$ at 180 days of storage for both strains). The growth rate of Trichoderma viride $01 \mathrm{PP}-8315$ and Trichoderma harzianum (Th Azad) in talc carrier is shown in Figure 7. Shahid et al. and Singh et al. [24,25] also reported that germination and seedling length along with seedling dry weight are important attributes, which determine the quality of seed of any seed lot. Besides these quality seed parameters seed vigor index also plays very crucial role in predicting the fate of any seed lot under biotic and abiotic stress conditions.

The sequence analysis and estimating the phylogeny thereupon has been done taking the rRNA sequences into account in all of the major organismal domains.In eukaryotes, genes encoding small subunit (SSU) and large-subunit (LSU) rRNA have been found to support a close sub-generic relationship. The genetic variability within 69 biocontrol isolates of Trichoderma collected from different geographic locations and culture collections and their phylogenetic analysis were done with the help of the sequence data obtained from the ITS-1 region of ribosomal DNA and a fragment of the translation elongation factor 1 (tef1) and reported that more than $50 \%$ of the potential biocontrol strains were grouped within Trichoderma section Pachybasium [25].

$\approx$ Average diameter of pathogen $(\mathrm{cm}) \quad$ Percent inhibition over control

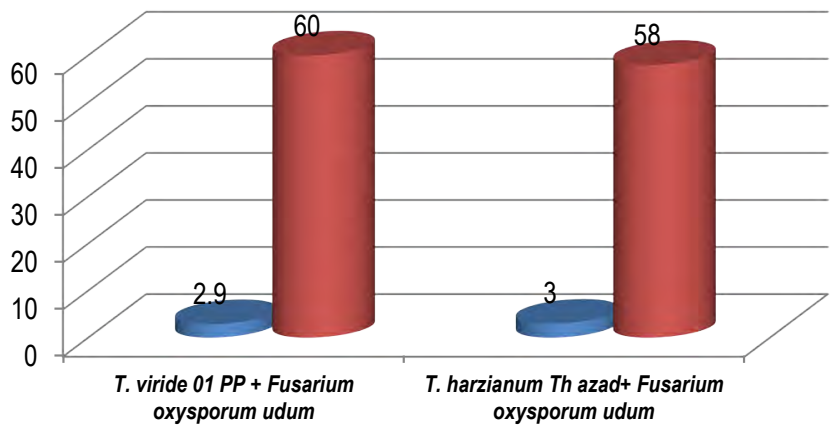

Figure 4: The suppression of the growth of pathogen was maximum with Trichoderma viride 01PP (60\%) followed by $T$. harzianum Thazad $(58 \%)$.

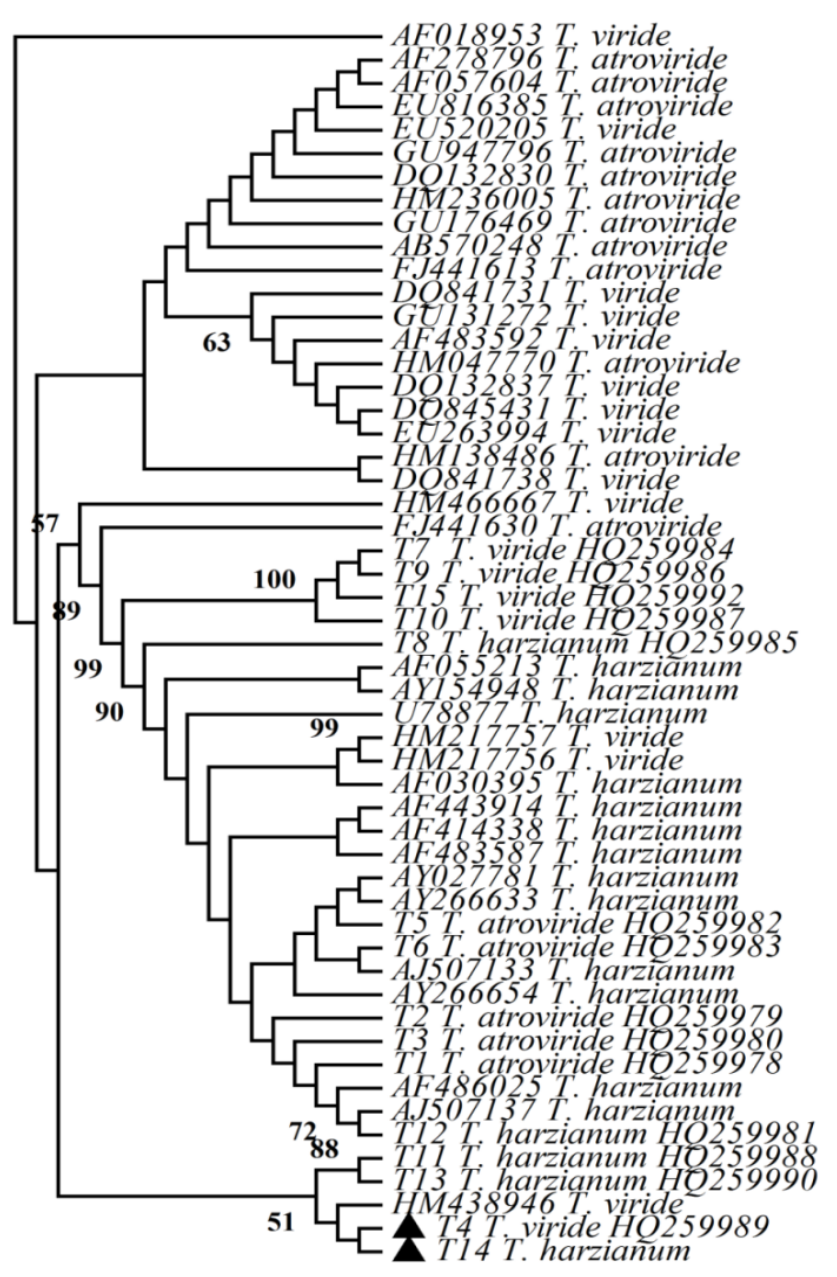

Figure 5: The evolutionary history was inferred using nearly complete ITS sequences ( $600 \mathrm{bp}$ ) using ITS 4 and 5 primers from 15 Trichoderma isolates and available NCBI sequences, constructed by Neighbor Joining method [11]. The optimal tree with the sum of branch length $=0.36770521$ is shown. The percentage of replicate trees in which the associated taxa clustered together in the bootstrap test (1000 replicates) is shown above the branches [21] The tree is drawn to scale, with branch lengths in the same units as those of the evolutionary distances used to infer the phylogenetic tree. All positions containing gaps and missing data were eliminated from the dataset (Complete deletion option). There were a total of 600 positions in the final dataset. Phylogenetic analyses were conducted in MEGA4 [12]. The scale indicates evolutionary distances computed using the Tajima-Nei method [22] and are in the units of the number of base substitutions per site. Filled diamonds indicate morphologically and biochemically identified highly efficient Trichoderma isolates. Gen bank accession numbers for each ITS sequence has been given with the each morphologically identified Trichoderma isolate in the dendrogram.

The identification of different Trichoderma isolates by molecular methods using ITS sequences has further characterized it into three main clades. Thus, a reliable phylogenetic tree was constructed with this data containing Trichoderma harzianum isolates. The shelf life study of Trichoderma has earlier been carried out on other strains such as Trichoderma longibrachaitum and Trichoderma atroviride. The shelf life of T. longibrachiatum in three different carrier materials (talc, lignite and charcoal) was determined at 30 days interval. The effect of temperature, $\mathrm{pH}$ and culture media for growth and sporulation of Trichoderma species was also done in a way to find out the ways to increase the shelf life of the bio-formulation. 
Citation: Shahid M, Srivastava M, Singh A, Kumar V, Rastogi S, et al. (2014) Comparative Study of Biological Agents, Trichoderma harzianum (ThAzad) and Trichoderma viride (01PP) for Controlling Wilt Disease in Pigeon Pea. J Microb Biochem Technol 6: 110-115. doi:10.4172/19485948.1000130

\begin{tabular}{|c|c|c|c|c|c|c|c|c|c|c|c|}
\hline $\begin{array}{l}\text { Name of } \\
\text { Strains }\end{array}$ & $\begin{array}{l}\text { Colony } \\
\text { Growth rate } \\
\text { (cm/day) }\end{array}$ & $\begin{array}{l}\text { Colony } \\
\text { colour }\end{array}$ & $\begin{array}{l}\text { Reverse } \\
\text { colour }\end{array}$ & $\begin{array}{l}\text { Colony } \\
\text { edge }\end{array}$ & $\begin{array}{l}\text { Mycelial } \\
\text { form }\end{array}$ & Mycelialcolour & Conidiation & $\begin{array}{l}\text { Conidiophore } \\
\text { branching }\end{array}$ & $\begin{array}{l}\text { Conidia } \\
\text { wall }\end{array}$ & $\begin{array}{l}\text { Conidial } \\
\text { colour }\end{array}$ & Chlamydospores \\
\hline $\begin{array}{l}\text { T. viride } \\
\text { 01PP }\end{array}$ & $8-9$ in 3 days & $\begin{array}{l}\text { Dirty } \\
\text { green }\end{array}$ & $\begin{array}{l}\text { Dark } \\
\text { greenish }\end{array}$ & Smooth & \begin{tabular}{|l|} 
Floccose to \\
Arachnoid
\end{tabular} & Watery white & $\begin{array}{l}\text { Ring like } \\
\text { zones }\end{array}$ & $\begin{array}{l}\text { Ball like } \\
\text { structure }\end{array}$ & Rough & Green & Not observed \\
\hline $\begin{array}{l}T . \\
\text { harzianum } \\
\text { Th azad }\end{array}$ & $8-9$ in 3 days & $\begin{array}{l}\text { Dark } \\
\text { green }\end{array}$ & Colourless & Wavy & $\begin{array}{l}\text { Floccose to } \\
\text { Arachnoid }\end{array}$ & Watery white & $\begin{array}{l}\text { Ring like } \\
\text { zones }\end{array}$ & $\begin{array}{l}\text { Highly } \\
\text { branched, } \\
\text { regular }\end{array}$ & Smooth & $\begin{array}{l}\text { Dark } \\
\text { Green }\end{array}$ & Not observed \\
\hline
\end{tabular}

Table 2: Morphological discriptors used in the characterization of isolated Trichoderma sp.

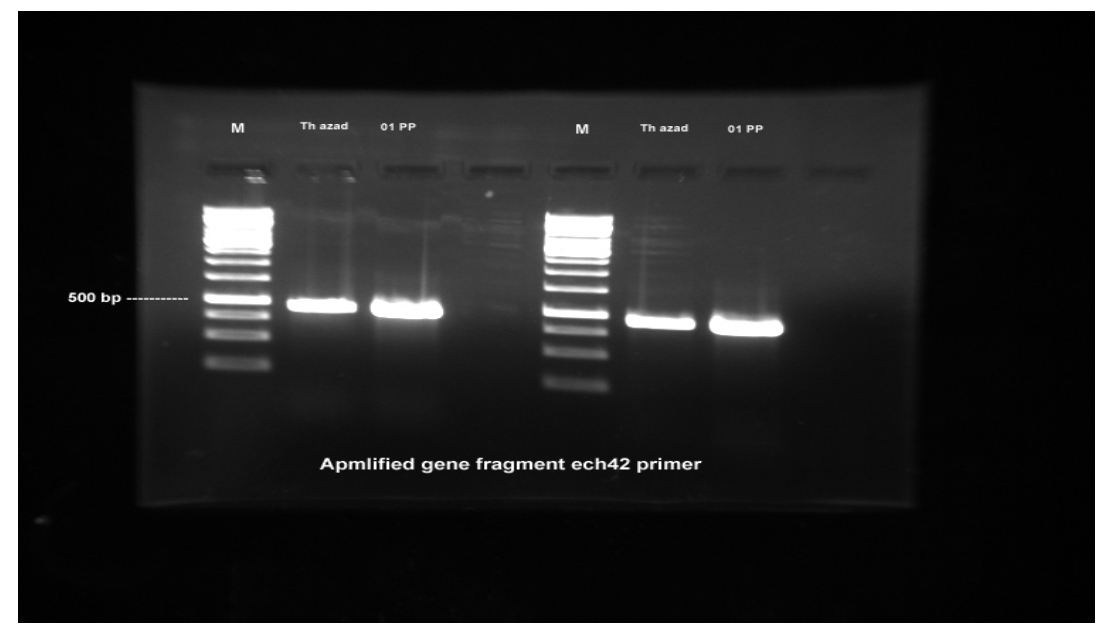

Figure 6: Amplified gene fragment ech42 primer Thazad and $01 \mathrm{PP}$

$\square$ Initial population $\square 30$ days $\square 60$ days $\square 90$ days $\square 120$ days $\square 150$ days $\square 180$ days

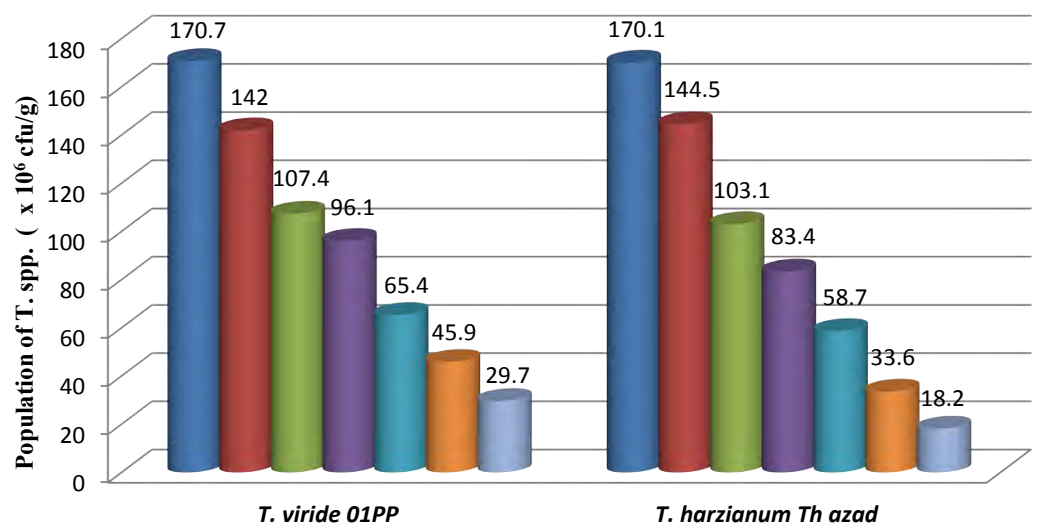

Figure 7: Effect of talc carrier on the population of Trichoderma sp.

\section{Conclusion}

T. harzanium (Th-azad) and T. viride (01PP) are potential biological controlagents and after comparative studies, it can be concluded that there are significant differences between T. harzanium (Th-azad) and T. viride (01PP) in controlling wilt disease in Pigeon pea.

\section{References}

1. Druzhinina SI, Seidl-Seiboth V, Herrera-Estrella A, Horwitz BA, Kenerley CM, et al. (2011) Trichoderma: the genomics of opportunistic success Nature Reviews Microbiology 9: 749-759.

2. Gajera HP, Bambharolia RP, Patel SV, Khatrani TJ, Goalkiya BA (2012) Antagonism of Trichoderma spp. against Macrophomina phaseolina: Evaluation of Coiling and Cell Wall Degrading Enzymatic Activities. J Plant Pathol Microb 3:149.
3. Weindling R (1932) Trichoderma lignorum as a parasite of other soil fungi. Phyto pathol 22: 837-45.

4. Ghisalberti EL, Rowland CY (1993) Anti-fungal metabolites from Trichoderma harzianum. J Nat Prod 56: 1799-1804.

5. Hanson LE, Howell CR (2004) Elicitors of Plant Defense Responses from Biocontrol Strains of Trichoderma viren. Phytopathology 94: 171-176.

6. Doyle JJ, Doyle JL (1990) Isolation of Plant DNA from fresh tissue. Focus 12 13-15.

7. Hiney M1, Dawson MT, Heery DM, Smith PR, Gannon F, et al. (1992) DNA probe for Aeromonas salmonicida. Appl Environ Microbiol 58: 1039-1042.

8. Crowhurst RN, King FY, Hawthorne BT, Sanderson FR, Choi-Pheng Y (1995) RAPD characterization of Fusarium oxysporum associated with wilt of angsana (Pterocarpus indicus) in Singapore. Mycol Res 99: 14-18. 
Citation: Shahid M, Srivastava M, Singh A, Kumar V, Rastogi S, et al. (2014) Comparative Study of Biological Agents, Trichoderma harzianum (ThAzad) and Trichoderma viride (01PP) for Controlling Wilt Disease in Pigeon Pea. J Microb Biochem Technol 6: 110-115. doi:10.4172/19485948.1000130

9. Zhang Z, Schwartz S, Wagner L, Miller W (2000) A greedy algorithm for aligning DNA sequences. J Comput Biol 7: 203-214.

10. Thompson JD, Higgins DG, Gibson TJ (1994) CLUSTAL W: improving the sensitivity of progressive multiple sequence alignment through sequence weighting, position-specific gap penalties and weight matrix choice. Nucleic Acids Res 22: 4673-4680.

11. Saitou N, Nei M (1987) The neighbor-joining method: a new method for reconstructing phylogenetic trees. Mol Biol Evol 4: 406-425.

12. Tamura K, Dudley J, Nei M, Kumar S (2007) MEGA4: Molecular Evolutionary Genetics Analysis (MEGA) software version 4.0. Mol Biol Evol 24: 1596-1599.

13. Altschul SF, Madden TL, Schäffer AA, Zhang J, Zhang Z, et al. (1997) Gapped BLAST and PSI-BLAST: a new generation of protein database search programs. Nucleic Acids Res 25: 3389-3402.

14. Cole JR, Wang Q, Cardenas E, Fish J, Chai B, et al. (2009) The Ribosomal Database Project: improved alignments and new tools for rRNA analysis. Nucleic Acids Res 37: D141-145.

15. Kusaba M, Tsuge T (1995) Phylogeny of Alternaria fungi known to produce host-specific toxins on the basis of variation in internal transcribed spacers of ribosomal DNA. Curr Genet 28: 491-498.

16. Vasudeva RS, Srinivasan KV (1952) Studies on the wilt disease of lentil (Lens esculenta Moench). Ind Phytopathol 5: 23-32.

17. Booth C (1971) The genus Fusarium, CMI, Kew, Surrey, England, 1-237.
18. Mukherjee PK, Verma A, Latha J (2002) PCR fingerprinting of some Trichoderma isolates from two Indian type culture collection a need for reidentification of these economically importance fungi. Sci Corres 83: 372-374.

19. Lübeck M, Poulsen SK, Lübeck PS, Jensen DF, Thrane U (2000) Identification of Trichoderma strains from building materials by ITS1 ribotyping, UP-PCR fingerprinting and UP-PCR cross hybridization. FEMS Microbiol Lett 185: 129134.

20. Felsenstein J (1985) Phylogenies and the Comparative Method. The American Naturalist 12: 1-15

21. Tajima F, Nei M (1984) Estimation of evolutionary distance between nucleotide sequences. Mol Biol Evol 1: 269-285.

22. Radheshyam S, Sumangala B (2011) Molecular cloning of endochitinase 33 (ECH33) gene from Trichoderma harzanium. African Journal of Biotechnology 10: $12156-12163$.

23. Shahid M, Singh A, Srivastava M, Sachan CP, Biswas SK (2011) Effect of seed treatment on germination and vigor in chickpea. Trends Biosci 4: 205-207.

24. Singh A, Shahid M, Pandey N, Kumar S, Srivastava M, Biswas SK (2011) Influence of temperature, $\mathrm{pH}$ and media for growth and sporulation of Trichoderma atroviride and its shelf-life study in different carrier based formulation. J Plant Dis Sci 6: 32-64.

25. Hermosa MR, Keck E, Chamorro I, Rubio B, Sanz L, et al. (2004) Molecular characterization of bio-control agents. Bulletin-OILB-SROP 27: 165-168. 